旧公衆衛生院を保存活用した 港区立郷土歴史館等複合施設 の基本設計プロセス

\section{BASIC DESIGN FOR CONSERVATION AND RENOVATION PROJECT OF FORMER INSTITUTE OF PUBLIC HEALTH TO A COMPLEX FACILITY IN- HOUSING THE MINATO CITY LOCAL HISTORY MUSEUM}

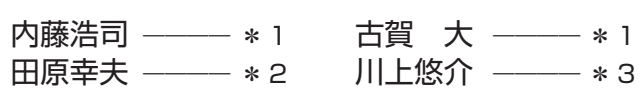

キーワード

リビングヘリテージ, 近代建築, 用途変更, 保存, 保存活用,

保存再生, 内田祥三, 歴史的建造物, オーセンティシティ,

インテグリティ, ミニマムインターベンション, 可逆性, バリアフリー

Keywords:

Living heritage, Modern architecture, Conversion, Conservation, Practical use, Revitalization, Yoshikazu UCHIDA, Historical building, Authenticity, Integrity, Minimum intervention, Reversibility, Barrier free

$\begin{array}{lll}\text { Koji NAITO } & * 1 & \text { Dai KOGA } \\ \text { Yukio TAHARA } & * 2 & \text { Yusuke KAWAKAMI }-* 3\end{array}$

There are growing demands for large scale modern architecture to be reused as "Living Heritage", however cases are still rare in Japan that implement utilization of modern architecture by conversion to be reborn as a different multi-use building. Coordination for the basic design of a complex facility in-housing the Minato City Local History Museum was based on a contemporary restoration idea of maintaining the authenticity and integrity of the historical building. This project and its process is a pioneering attempt for the revitalization of modern architecture, and expected to be a guideline for the future.

\section{1.はじめに}

旧公衆衛生院建物は、「公衆衛生技術者の養成及び訓練並びに公衆 衛生に関する調查研究機関」注1) として、1938(昭和 13) 年に米国ロッ クフェラー財団の寄付を受けて港区白金台の地に建設された。設計 は内田祥三、施工は大倉土木株式会社により、地下 2 階、地上 5 階 注 2)、塔屋 3 階の鉄骨鉄筋コンクリート造で、延床面積が約 15,000 $\mathrm{m}^{2}$ の「内田ゴシック」注3) の外観を有する歴史的建造物である。2002 (平 成 14) 年に国立保健医療科学院へ改組された後、埼玉県和光市に移転 され建物は閉鎖された。その後、2009(平成 21) 年に港区が国から土 地と建物を取得した。港区は、この建物を保存し、かつ区民等の活用 に供するため、郷土歴史館、がん在宅緩和ケア支援センター、子育て 関連施設、区民協働スペース等の整備計画「旧国立保健医療科学院整 備活用基本計画 (以降、基本計画)」を2013 (平成 25) 年に策定した。

明治から第二次世界大戦までの近代建築を、本計画の様に保存し ながら創建当初と異なる大規模な複合用途へ用途変更をして活用寸 る例はこれまで国内においては極めて稀である。歴史的建造物を次 世代一継承するにあたり、建物のオーセンティシティ(真実性) 注 4 )、 インテグリティ（完全性） 注5)を守りながら、新しい用途での活用の ために現代の要求機能をどう満足させるかが大きな課題となる。計 画時、この建物は文化財等には指定されておらず、建築基準法第 3 条 1 項一号、二号による法の適用除外にはならないため、現行法規を全 て満たす必要があった。また、港区の区有公共施設として、特に安全 で安心して利用できることを求められた。

本稿は、基本計画に基づき、港区立郷土歴史館等複合施設として保 存再生するための、改修基本設計における設計プロセスをまとめた ものである。港区では 2014 (平成 26) 年に基本設計者の選定をプロポ
ーザルにより行い、株式会社日本設計を選定した。実施設計以降はデ ザインビルド方式により工事施工とともに実施設計者が選定される 予定であったため、それを前提に基本設計を進めた。

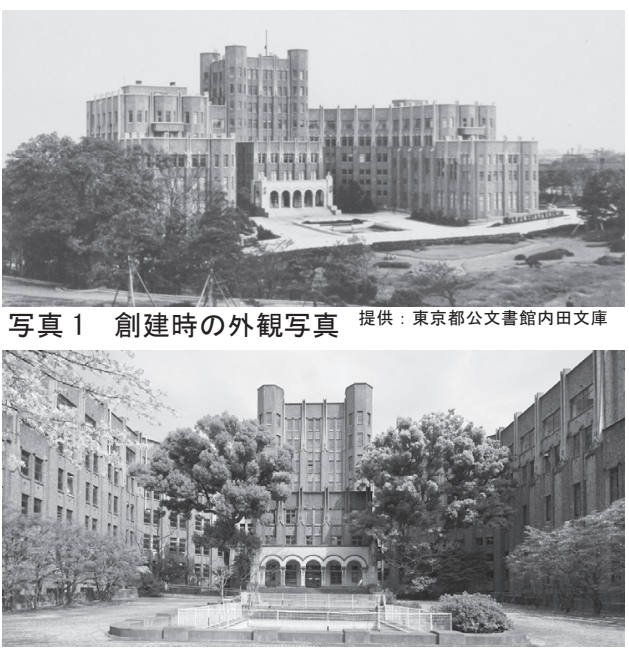

写真 2 改修前の外観写真 提供 : 港区

\section{2. 基本調査}

活用のために何をどのように手を加えるかといった検証のために、 建物の現状及び改修履歴の調査は極めて重要である。本改修設計に 先立ち、基本計画段階の調查及び検討資料を元に、不足している調査 を実施し建物の状態を分析した。

\section{1 創建時の設計図書等の文献}

国から移管された港区所蔵の資料、東京都公文書館内田文庫や東 京大学所蔵の資料に、建物本体の設計図のみならず仕様書や外構擁

\footnotetext{
(株)日本設計

( ( 163-1329 東京都新宿区西新宿 6-5-1＼cjkstart新宿アイランドタワー 29 階)

京都工芸繊維大学 特任教授

港区立港郷土資料館
}

\footnotetext{
NIHON SEKKEI, INC.

Project Prof., Kyoto Institute of Technology Minato City Local History Museum
} 
壁の詳細を含めた創建時の設計図書注 6 )が残されており、当時の仕上 仕様や躯体状況の検証を行った。外壁サッシュについては創建時の 製作方針や後年の改変履歴注 7) の詳細も判明した。内田祥三の作品集 や研究論文は少なく、東京大学の協力により希少な資料注8) を手し 参考とした。

\section{2 建物の敷地および外構}

敷地は南の目黒通りから北にかけて建物 2 層分の高低差で下がっ ており、建物の入口は傾斜に応じて設けられている。建物内はこの傾 斜を利用し、階高が必要な大空間が断面上合理的に配置されている。 その反面、廊下の段差が各所に存在し、活用に際してはバリアフリー 対応が特に重要となる。

隣接寸る東京大学医科学研究所 (以降、医科学研) も内田祥三の設 計である。創建時の資料によると一体的な計画のもとで一対の建物 として計画している。本建物のアプローチも医科学研正門からが主 であったが、港区への所有移転の際に目黒通りに面して接道を確保 した。外構では西側正面の池を中心に舗石舗装を含めて、創建当時の ものがよく残されていた。創建時の動物舎の他、後年建てられた附属 棟が敷地北側に存在する。

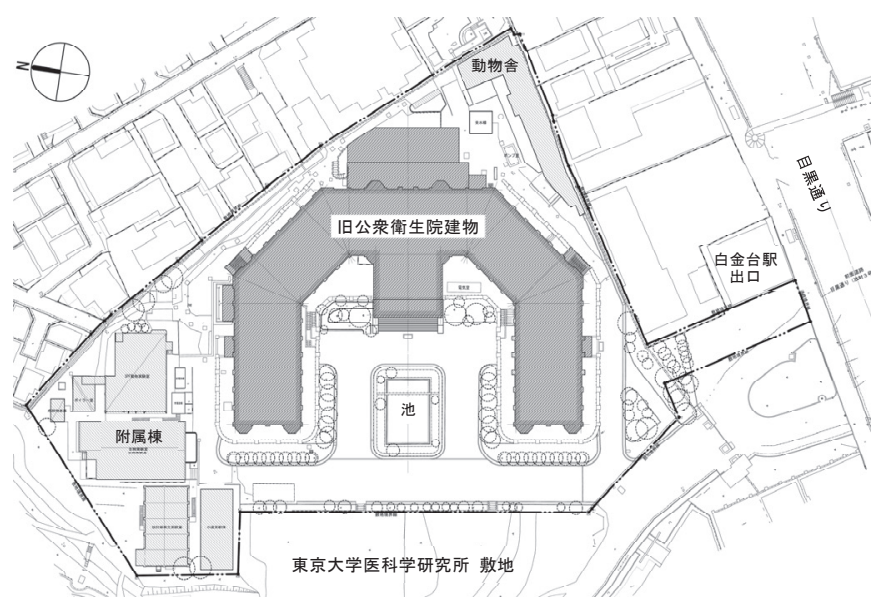

図 1 改修前建物配置図

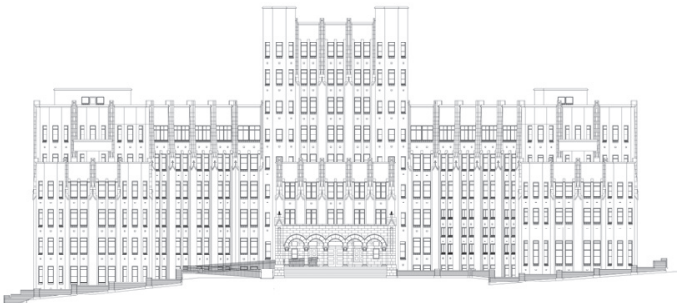

図 2 改修前建物西側立面図（南北に高低差がある）

\section{3 外装の状況}

中央部のタワー部と両側に広がるウィングで構成された左右対称 に近い建物ファサードは、内田祥三の他作品同様に強い正面性を備 えている。外部仕上は全面に渡りスクラッチタイルを用い、正面エン トランスと側面サブエントランスの一部は石貼りである。「内田ゴシ ック」の特徵でもある尖塔状のピラスターには擬石、細かな装飾や空 台にはテラコッタを用いている。

開口部のサッシュは出入口扉等一部を除き、創建当初の鋼製建具 から建具枠を残したままのカバー工法でアルミ製建具に改修されて いた。しかしサッシュ以外の通常望見できる範囲では、後年に改変さ れた形跡等もなく、創建時の外観が極めて良く保たれていた。
外壁の劣化調查は基本設計段階では、柱に挟まれた 1 スパンの上 から下までを、南・北・西 3 面の打診調查を行なった。主な劣化状態 はタイルの下地モルタルからの浮きで平均 $20 \%$ であったが、北面に 対して西・南面の劣化が著しい状態であった。タイルはスクラッチが わらび面状になっており、現代のメーカーが特注製作したタイルと 比較を行ない、修理で補填するための新規製作は可能であると判断 した。

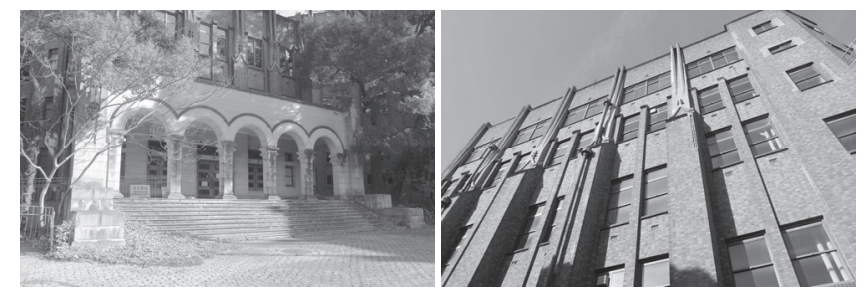

写真 $3 \cdot 4$ 外装の状況（左：正面エントランス、右：南側外壁）

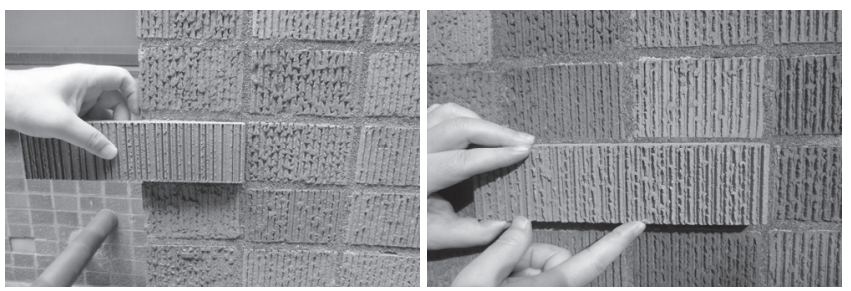

写真 $5 \cdot 6$ メーカーのタイルと比較（左：既成品、右 : 特注品）

\section{4 内装の状況}

本建物は、公衆衛生に関する研究室や実験室が大半を占める。5階 にあった寮室は研究室等に改変されていたが、その他の内装部分は 塗装のやり替え以外、壁に設けられた長押等を含め創建時の意匠が 良好な状態で保たれていた。内部建具は木製建具の意匠を模した鋼 製建具が多く用いられ、丁番等の建具金物の状態も良好であった。居 室が面する廊下には格天井が残され、後年取り付けられた照度不足 を補う照明や設備配管以外は、創建時の意匠が良く保たれていた。

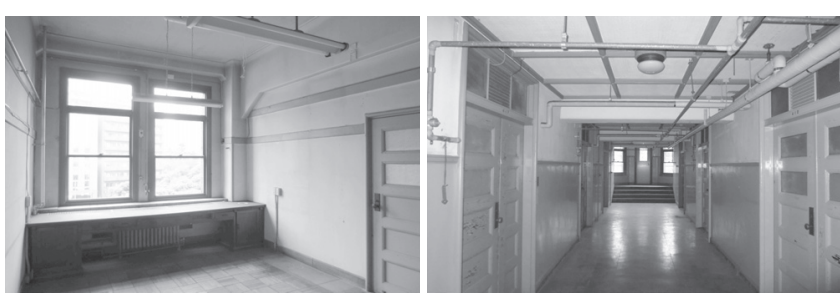

写真 $7 \cdot 8$ 内装の状況 1 (左 : 研究室、右 : 廊下)

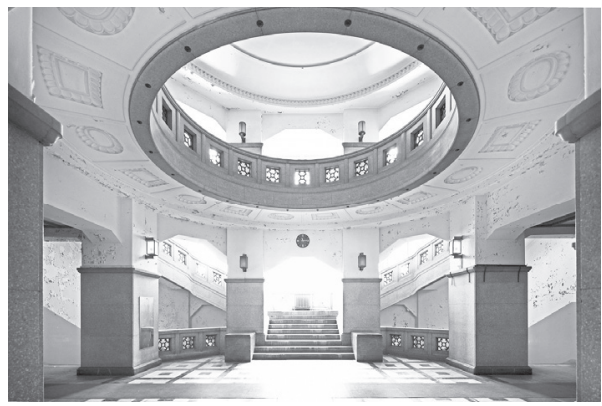

写真 9 中央ホールの吹抜空間 提供: 港区

中央ホールの吹抜空間、天井の高い講堂や図書閲覧室の大空間、木 質内装の院長室・次長室などの内装は、他の室とは異なる特徽的な内 部意匠・ディテールが施されている。中央ホールは、円形の吹抜けを 
中心に、石材（テラゾーを含む）を床及び腰壁に用い、天井は白漆喰 (現状は表面に塗装)で仕上げた空間である。天井の漆喰やテラゾー の手摺に施されたレリーフ装飾が華やかさを演出している。大空間 である講堂、図書閲覧室では、板張りの腰壁に天井は格天井と他では 見られない意匠であり、入口建具も他室の鋼製建具と異なり木製建 具が用いられている。院長室では壁を全面的に自然木で仕上げた内 装であるが、建具は鋼製建具を用いている。他にも、2 層の空間を利 用した積層書架はほぼ創建時のまま残されていた。また中央ホール に近接する広いトイレの $1 \cdot 2$ 階部分の内装仕上には創建時の大理 石が残されていた。

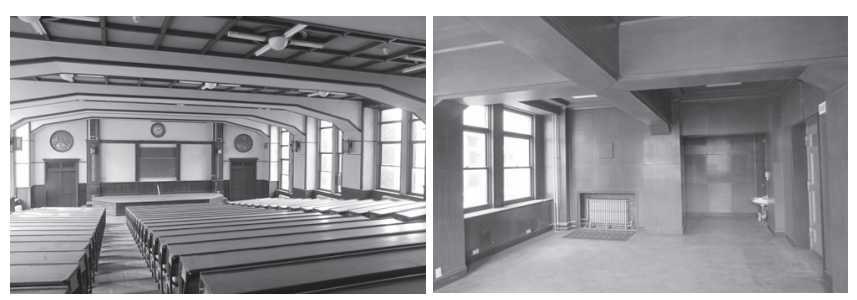

写真 $10 \cdot 11$ 特徵的内部意匠（左：講堂、右：院長室）

基本設計段階では、概ね全室にわたり内装仕上の状況調查を行い、 各室内 4 面を写真撮影して記録に残した。内部の鋼製建具について は非破壞調査にて板厚を測定し、防火設備として所定の厚さが確保 されていることを確認した。一方で扉の有効寸法は、現行のバリアフ リー法上僅かに不足しているため改変が必要であることが判明した。 また石製の沓摺りには段差が $2 \mathrm{~cm}$ 程度あり、バリアフリー動線上で は改善が必要であった。

\section{5 躯体および設備の状況}

港区では基本計画策定前の 2009 (平成 21) 年に、建物の耐震診断評 定を行なっていたため、基本設計段階の構造に関する調查は敷地内 の地盤と外構擁壁の部分調查に限定した。耐震診断時の調查報告並 びに外壁調査の際に屋上パラペットの内側にて一部はつり調査によ り、コンクリートの中性化は進行していないことが判明している。室 内の躯体状況は、後年施工の設備配管等による大きな躯体欠損も見 受けられない良好な状態であった。

室内に冷房設備はなく、空際に設置されたスチーム暖房器が残さ れていた。実験用の排水・換気設備等は後年に追加設置されているが、 躯体貫通はせずに創建当初から設けられていた梁スリーブを通すか 梁下に露出するなどで対応していた。施設移転後本建物は長く使用 されていなかったため、全設備の更新が必要と判断した。しかし特別 な内部意匠を施した部分には、創建時の特徴的な照明器具が残され、 文化財的価值が高いものと考え再生利用すべきと判断した。
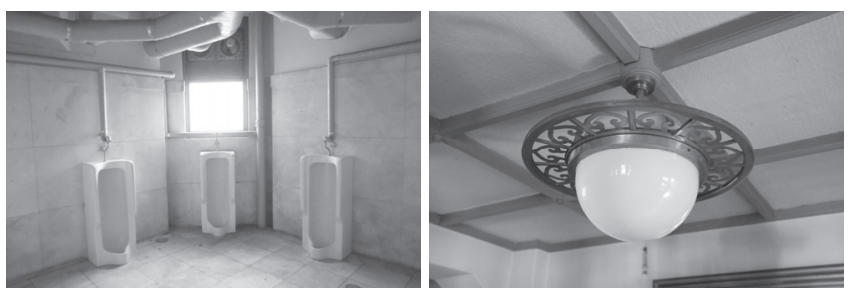

写真 $12 \cdot 13$ 内装の状況 2 (左 : 2 階トイレ、右 : 照明器具)

\section{3. 基本設計}

3. 1 基本理念と設計の原則
歴史的建造物の保存改修では、解体時に新たな事実が発見される など様々な困難が予想されるため、有識者等への意見聴取を踏まえ、 改修工事全体を通して常に立ち戻ることのできる、基本理念と設計 の原則を策定した。以下は全文である。

\section{(1) 基本理念}

建物の本質的価值を踏まえ、保存、復原、活用それぞれにおいて、 あるべき姿を追求し、正しいプロセスのもとに方針を決定し、全体が 統合されバランスのとれた「生きた文化遺産」(リビングヘリテージ： living heritage) として再生する。

旧公衆衛生院の本質的価值とは、以下の部分が総合的に構成する 文化遺産としての価值である。

(1) 旧公衆衛生院の建築として意匠・材料・技法がオリジナルの状態 をよく保っている部分。

(2) プロフェッサーアーキテクト・内田祥三の代表的作品として特徵 的な部分。

(3) 創建以来使い続けられてきた「生きた文化遺産」の寸べての時代 を象徵する部分。

\section{( 2 ) 設計の原則}

保存・復原・活用の設計における原則を下記の通り定める。なお設 計に当たっては、事前に十分な調查を行い、それに基づいた各部分の 価值づけを明確にした上で、港区及び港区文化財保護審議会等との 合意のもとに詳細を決定する。改修後に、港区の文化財として指定を 受けることが可能な設計を行う。

\section{(1) 保存について}

貴重な 20 世紀の文化遺産として、以下の内容に考慮して保存部分 を決定する。<旧公衆衛生院としての特徴的部分 $><$ 内田祥三の代 表的作品 $><$ 医科学研との一体の環境 $>$

なお保存設計は、創建以来の各時代の貢献を無視してはならず、ま た建物が恒久的に維持できる技術的・財政的検討を踏まえたもので なければならない。

(2) 復原について

建物の本質的価值を踏まえ、文化遺産としての継承に必要な部分 は創建時の意匠に復原する。ただし復原に当たっては十分に信憑性 のある資料に基づくことを原則とし、決して推測が入り込むことの ないように注意する。さらに、現代の施設としての活用にも考慮し、 場合によっては現代の技術の導入による復原も検討する。

(3) 活用について

国の研究施設であった建物を港区の複合施設として転用のため活 用設計するにあたっては、来訪者が歴史を感じながらも使い易く親 しみやすいデザインとすることが重要である。また、建物は安全性・ 機能性には十分な配慮を行うとともに、将来の維持管理についての 明確な方針を踏まえたものでなければならない。

\section{2 設計条件の確認}

改修工事の計画条件として下記の 5 点を確認した。

(1) 歴史的建造物として保存寸るための補修・修理を行う。

(2) 区民のための複合施設として活用するための改修を行う。

(3)建築関連法規に適合させる改修をして、用途変更を行う。

(増築、改築、大規模な修繥・模様替には該当させない。)

(4) 耐震補強を行い、耐震性能を確保する。

(5) 改修工事完了後、港区有形文化財（建造物）に指定を予定寸る。 


\section{3 計画概要}

基本理念と設計の原則に基づき、保存・復原・活用の各計画につい て基本設計を進めた。その内容は、文化遺産に関する世界的・歴史的 文書注9) に述べられた主要な原則・理念に基づき、特に下記の点に注 意してまとめられた。

- 建物の本質的価値の明確化

・手を加える際の新旧の区別と可逆性（リバーシビリティ）

- 復原時の推測の排除

・材料の修理も含め、改修工事にて付加や改変など手を加える範囲 を最小限に抑えるミニマムインターベンション

・オリジナルを撤去する場合、記録と痕跡を残すことに配慮

\section{(1) 保存計画}

(1) 保存部分の設定

建物の本質的価值を踏まえ、文化遺産としての価值が具現化され ている部分を抽出し保存する方針とした。具体的には、「旧公衆衛生 院としての特徵的な部分」として旧講堂、旧研究室、主要廊下等の内 装デザイン、「内田祥三の代表的作品」として外装デザイン、正面ア ーケード、中央ホール等、「医科学研との一体の環境」として外構デ ザイン、植栽計画等の創建時の姿を残す部分である。

この設定に基づき、改修計画を進めながら、各エリア（部分）と部 位の保存ランクを設定した。完成後の文化財指定及び保存活用計画 策定老視野に入れ、「重要文化財（建造物）保存活用計画策定指針」 に準拠し、全館にわたり「保存部分」、「保全部分」、「その他（整備） 部分」に分け、各室全ての仕上部位を基準 $1 \sim 5$ に設定した。

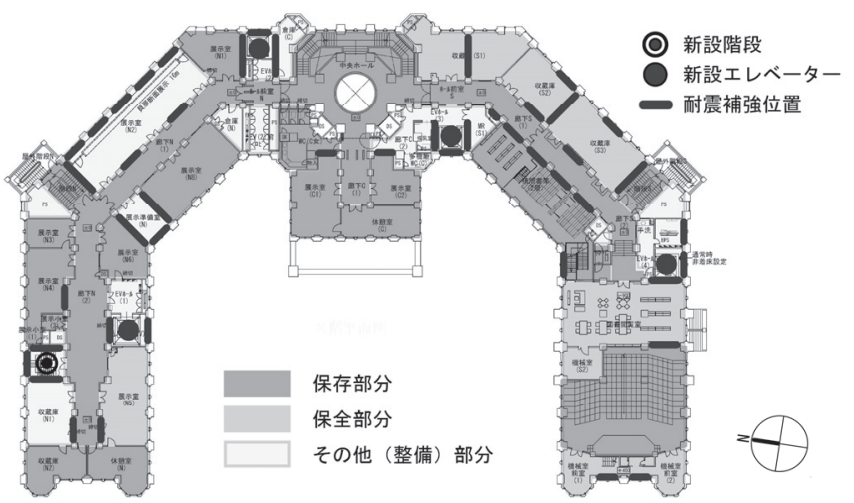

図 3 各部分の保存ランク設定例（2 階平面図）

\section{(2) 材料の保存・補修}

現存する当初材が、将来にわたり同一位置で保存・維持できる修理 工法の選択に努め、材料種別と劣化状況別に細かく設定した。安全 性・機能性の面で材料を置換せざるを得ない場合には、他の保存部分 と調和しつつ区別可能なデザインとすることを原則とした。

(3) 記録・部材の保存

これまで判明している創建時や改修履歴の図面等の記録を一覧に してまとめ、今後設計・工事で判明したことは、図面・写真等による 記録を行い、合わせて保存する方針とした。また、工事で撤去される オリジナル部位の断片を資料として保管する方針を設定した。

\section{(2) 復原計画}

(1) 復原部分の設定

オリジナル部位が欠失している箇所を抽出し、重要な箇所は復原 を行うことを目標とした。具来的には、正面左側に増設されたスロー
プにより床の一部が改変された正面のエントランスポーチや、一部 が久失していた創建時の照明器具、鋼製の外壁建具などである。

(2) 復原の手法

オリジナルが持つ精神を継承し材料と工法は創建時のものを基本 とするが、安全性・機能性において十分ではない場合は現代技術を用 いる方針とした。

エントランスポーチは、創建時の図面等資料と欠失してない側の 現況に基づき、創建時の意匠に復原できると判断した。照明器具は部 分欠損を残された部位から復原し、光源を LED に置換して使用可能 と判断したが、玄関ホールのシャンデリアは完全に除却されていた ため、2 方向の面が写る写真を基に復刻を目標とした。鋼製の外壁建 具は枠以外欠失しており、附属棟の動物舎に残された創建時建具亡 当時のメーカー資料を根拠に、一部に復原することを目標とした。
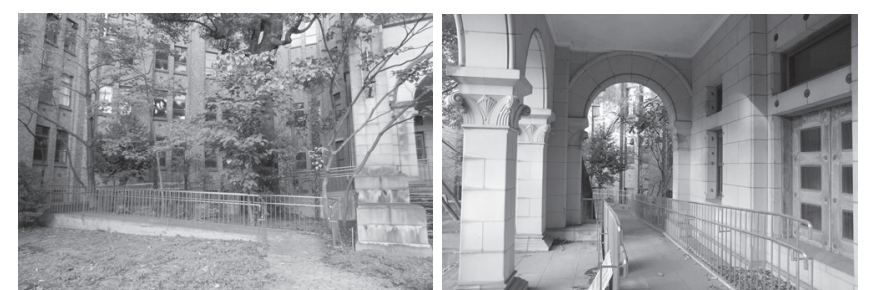

\section{写真 $14 \cdot 15$ 復原設定箇所}

（左：増設された既存スロープ、右：改変されたポーチ床）

\section{（3）活用計画における共通方針}

この建物の大部分を郷土歴史館として活用することなど、整備す る各施設の概略ゾーニングは基本計画にて策定されていた。その基 本計画に基づき基本設計を進めるにあたり、建築、構造、設備などの 各計画における共通方針として以下を設定した。

(1) 施設計画の方針

歴史的建造物が持つ空間特性を最大限活かして、来訪者が「生きた 文化遺産」を身近に感じられる施設とし、活用により本建物の文化遺 産としての価値を損敞ることのない計画とする。

具体的には、中廊下型の居室配置は原則そのままとし、特殊な内装 室 (院長室・講堂等) 以外の典型的な研究室なども極力保存の上で活 用寸る。そして、過度な改変（間仕切壁位置や仕上材の大幅変更）や 付加（直天井空間に天井設置等）を避ける方針とする。

\section{(2) 法令の遵守}

安全で安心して利用できる公共施設とするため、建築物としての 関係法令の遵守を前提とする。建築基準法、消防法、バリアフリー法 等の規制事項は行政協議を含めて必要条件を整理し、可能な限り才 リジナルを残しながら必要な改変方法を定める。また用途変更の際 に既存遡及される法的要件以外の既存不適格部分についても、可能 な限り現行法規に準拠して安全性を高める方針とする。改変方法と して、バリアフリー動線上の室入口の沓摺り段差の解消には、両端に 痕跡を残した上で平坦に削り取る最小限の方法などを提案した。

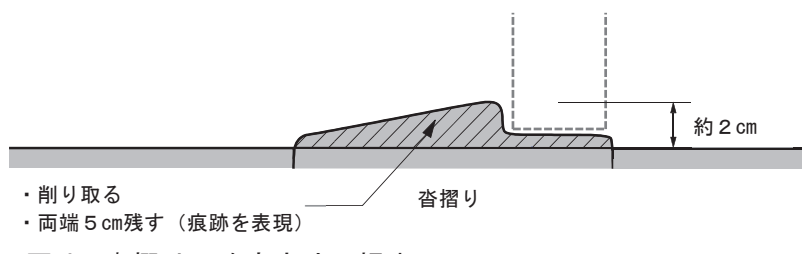


(3) オリジナル部位の活用

活用に伴い撤去が必要な場合は、記録の保存と共に、別な場所や用 途での再利用も考慮する。文化財保存の原則として、オリジナルの状 態が改変された部分は、オリジナルと区別できる仕上とすべきであ るが、場合により、空間のデザイン的統一性を優先しオリジナル部材 の移動を可とする。例えば、耐震補強において増厚補強された新しい 壁面に、当初の既存壁にあった仕上材を取り付けることなどである。

(4) 活用のための付加・置換、及び付加物のデザイン

活用において安全上・機能上必要になる付加や置換は、建物の文化 遺産としての価值への影響が最小化できる手法を検討する。付加物 のデザインは、材料の置換の場合と同様、保存部分と調和しつつ区別 できる事を原則とする。将来の必要機能の変化による変更や取り外 し時に、現状に戻すことのできる「可逆性」に配慮する。例えば、活 用上必要な新設間仕切壁等の付加物は、乾式工法とするなどである。

\section{(4) 建築計画}

各施設のゾーニングは、既存建物を効果的に活か寸配置に考慮し、 敷地入口に近い南翼部分を、子育て関連施設、がん在宅緩和ケア支援 センター、区民協働スペースの各用途を集中させ、郷土歴史館と閉館 時間が異なっても支障が生じない配置とした。室の計画はオリジナ ルの間仕切壁を極力活か寸一方、将来的に活用しや寸い 2 スパン以 上の部屋になるプランニングをめざした。

建物への入口、階段、中廊下の動線は、基本的に既存建物の状態を 踏襲する一方、避難上不足する階段を一部に新設した。エレベーター は創建当時のシャフトの大きさでは更新できないため、新たな場所 にシャフトを設置し、同一フロア内の段差は、近傍に段差解消機を新 設してバリアフリー化を図った。

各施設の計画概要は以下の方針でまとめた。

(1) 共用部

中央ホールは保存部分として内装意匠を厳格に保存するが、吹抜 手摺の安全対策、補助照明など活用に際して必要な付加を行なった。 廊下も創建時の意匠を保存する方針とするが、保存の優先順位は、1 〜 3 階、4・5階、地階の順と設定した。建築基準法上、中央ホール は避難階段、廊下は避難経路となることから、防火区画、避難通路の 確保、内装の準不然化など改変を必要とした。また、システムトイレ の採用等で床スリーブを少なくして既存躯体への負担を軽減した。

(2) 郷土歴史館

歴史館としての機能を満足させるとともに、来館者がこの歴史的 建造物の特徵をしっかりと体験できることを目標とした。常設展示 室は建物端部まで来館者を導くレイアウトとし、中廊下と標準的な 居室の創建時の内装を活か寸意匠方針とした。企画展示室、特別収蔵 庫、一時保管庫は、外壁との間に熱的外乱を防止する空調バッファー ゾーンを設けた。展示収蔵施設以外では、カフェを従前の食堂の位置 に配置し、内装タイルをオリジナルのまま活用する方針とした。

(3) 子育て関連施設

乳幼児の利用施設は避難階でもある地下 1 階へ、学童クラブは眺 望の良い 5 階への配置とした。地下 1 階の南翼部と 5 階はオリジナ ル内装が比較的残っていないため、子どもの安全を第一にした内装 仕上に改変する方針とした。内装仕上はクッション材の設置などに も考慮しながら明るい空間づくりをめざすこととした。

(4) がん在宅緩和ケア支援センター
セットバックしている 3 階屋根部分をバルコニーとして利用でき る 4 階への配置とした。4 階の内装は保存状態が良いことから、オリ ジナル内装を活用し家庭的なくつろぎのある空間をめざすこととし た。オリジナル壁を撤去する部分は、壁の痕跡が意匠に反映できるよ うに考慮することとした。

(5) 区民協㗢スペース

5 階で中央ホールからアクセスしやすい配置とした。オリジナル 意匠の残されていない部分であるため内装を一新する方針とした。

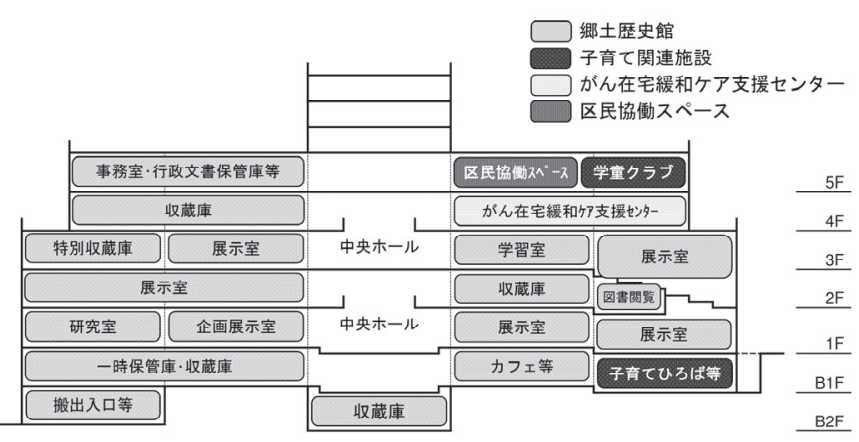

\section{図 5 各施設の配置断面}

\section{(5) 構造計画}

耐震補強の方針として、各施設および室の配置に配慮し、鉛直方向、 平面配置とも均衡のとれた補強計画とした。既存 RC 壁は原則残すこ とを前提とし、鉄骨ブレースは接着工法の採用検討など既存躯体の 保存にも配慮した計画とした。既耐震診断評定時の建物情報および 推定構造設計図等を基に、現行耐震診断基準に基づいて耐震診断の 再解析を実施した。

基本設計では、免震化と耐震化について比較評価を行い、耐震化を 採用寸る事を再確認した。本建物は傾斜した敷地と周囲のドライエ リアにより地下ピットが大幅に深くなり、免震化は耐震化に比べて 改修費用が大幅増になると想定された。耐震化は増厚壁やブレース の付加による建物内での改変が免震化より多くなるものの、免震化 のように建物上屋が大地と切り離され土地との関係性が失われるこ とはない。これらの考察と、耐震要素と室の配置や保存部分への影響 を鑑み、本建物には耐震化が適切であると判断した。

\section{（6）設備・環境計画}

設備については今回の活用に際し、残された創建時の照明器具を 除き一新する計画とした。歴史的建造物を次世代にわたり快適に活 用していく上で、時代に合わせて適切な設備システムへ容易に更新 可能な計画をめざした。

設備ルートは、既存 $\mathrm{EV}$ シャフト等の竪穴ルートや廊下天井内の比 較的大きな梁の既存スリーブを利用し、新設する躯体開口を最小限 として既存躯体への負担を軽減する方針とした。保存部分をはじめ とする創建時の仕上に新設する設備は、機器類が露出する場合が多 くなるため、配線や配管を含めて意匠上の調和を図る配置とした。

環境負荷低減策として、屋根と外壁への断熱材の新設や更新する 外壁サッシュへのペアガラス採用などの建築計画と併せながら、現 代の複合施設の環境基準で各施設および用途に応じた設備計画を設 定した。特別収蔵庫や企画展示室では 24 時間運転可能な恒温恒湿空 調を採用した。一般展示室と収蔵庫は直接外気取入を避け、制御性の 良い中央式の外気処理機を導入する方針とした。 
東日本大震災でのインフラ復旧の経験より、空調機には GHP 方式 を採用した。災害時に在館者が䚻宅困難に陥ることを想定し、館内で 待機・滞留できる室を限定し、非常用発電機を 72 時間連続運転でき る方針とした。

\section{( 7 ）外構計画}

外構においても基本理念と設計の原則に基づき、医科学研との一 体の環境を保存・復原することを前提とする計画を基本とした。

南側の敷地入口から正面エントランスへの既存通路は、敷地傾斜 のためバリアフリーの基準を満たすことができず、法的なバリアフ リー動線は建物南側の入口と設定した。ただし、正面入口からのアプ ローチも考慮し、新規のスロープを設ける計画とした。

正面エントランス前の外構の保存の優先順位を高く設定し、後年 フェンスが回されていた池の外観を復原し、舗石舗装（ピンコロ）を 極力保存し、植栽は剪定程度に留めて残寸計画とした。池は安全刘策 上、創建時の設計図に記載された低木を周囲に植えて近づきにくく するとともに、池の深さを浅くする方針とした。

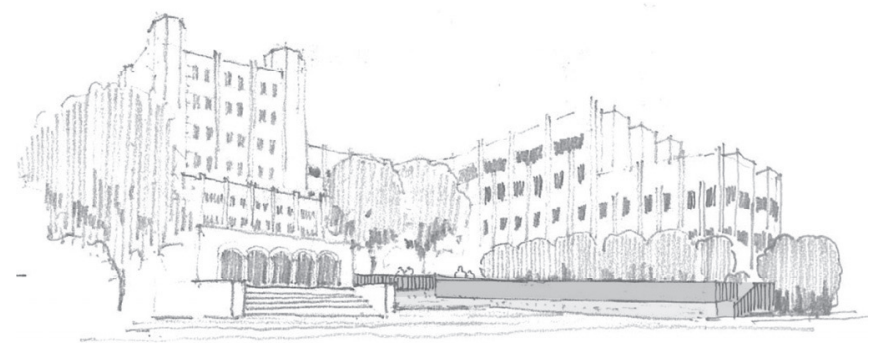

\section{図 6 新規スロープ計画のイメージ}

\section{（8）展示関連計画}

展示施設としては、国指定文化財を展示する際に個別に申請を行 う「公開可能な施設」として整備を行うことを前提とした。展示空間 については、本建物の空間特性を活かし、空間自体も展示資料と位置 付けることとした。

企画展示室は耐震性能に影響のない範囲で壁を撤去し様々な展示 に対応できるようにし、常設展示室は中廊下型で小割の既存室を極 力そのまま活用するため、室毎の小テーマを設けて必ずしも順路に 従わなくても可能な展示計画を進めた。天井は既存の直天井のまま とするため、露出する設備配管、ダク卜類は整理して配置する方針と した。室の入口扉は概ね親子扉が既存であるが、バリアフリーにおけ る親扉の有効幅が僅かに不足するため、開放固定による運用方針と し、開口幅員を確保して既存扉を保存する方針とした。

収蔵庫は収蔵資料に応じた定量的なランク分けを設定し、建物内 での配置を考慮した上、必要な温湿度環境に応じた内装および設備 計画を行った。その他、資料搬出入口、資料専用エレベーター等の設 計においても「公開可能な施設」の基準を満たすこととした。

\section{4.まとめ}

20 世紀に造られた大規模な近代建築が、重要文化財をはじめとす る文化財の指定を受ける一方で、生きた遺産 (リビングヘリテージ)」 として現役の建築として使い続ける要望が増えてきているが、本計 画では新しい用途に対応した活用設計を行う場合においても、旧公 衆衛生院の文化遺産としてのオーセンティシティとインテグリティ
を重視し、可逆性やミニマムインターベンション等の現代の修復理 念に配慮した。特に、積層した歴史を大切に残しながら現代の活用を 実現するという設計プロセスは、これまでに前例のない試みである と考える。本計画が、今後の近代建築の保存活用における一つの指標 となれば幸いである。

なお、本報告は基本設計までのプロセスであり、実施設計と工事監 理段階で、さらに保存・活用の詳細を決定しているが、概ね基本設計 にて設定した方針が踏襲されている。これについては、筆者を含め実 施設計以降の担当者の報告に委齐たい。

\section{5. 謝辞}

最後に、設計過程で適宜ご指導いただいた港区文化財保護審議会 委員でもある藤井恵介東京大学大学院教授、並びに資料提供に協力 いただいた角田真弓氏 (東京大学)、杉山貴則氏 (大成建設設計本部) に謝辞を申し上げる。

\section{注記}

注 1）国立保健医療科学院ホームページ「国立公衆衛生院の沿革」より。

注 2）本稿における階表記は、創建時の設計図書及びこれまでの建物使用時と 同じとした。現行法規上は異なり、「地下 1 階、地上 6 階」となる。

注 3）東京大学本郷キャンパスをはじめとする多くの内田祥三作品のファサ 一ドは、内田創案の特徴的な意匠で構成され重厚なネオ・ゴシック建築 の印象を与え、「内田ゴシック」と呼ばれる。

注 4）歴史的遺産における本物としての価値。「ヴェニス憲章」に明記され、 その後ユネスコ世界遺産（文化遺産）の評価基準となった。

注 5）ユネスコ世界遺産（自然遺産）の評価基準であったが、文化遺産も含む 世界遺産全体の評価基準となった。遺産の価值を構成する必要な必要な 要素が全て含まれているという意味を持つ。

注 6)「公衆衛生院建物新築工事設計書（表紙共 42 枚、添附図面 51 葉 : 公衆 衛生院建築設計図) 」、「本館周囲舗装排水貯水池取設其他工事設計書 (配 置図平面図、詳細図（3 葉）を含む)」、「敷地境界擁壁新設其他工事（7 葉)」による。

注 7）「公衆衛生院第 2 工区建具改修その他工事, 昭和 55 年 9 月」による。

注 8）東京大学本郷キャンパス関連資料を含めて入手し、内田作品を直接論じ たものは以下の 2 点。「内田祥三先生眉寿祝賀記念作品集刊行会編 : 内 田祥三先生作品集, 鹿島出版会（非売品）, 1969.11」「「杉山貴則：内田 祥三のファサード構成, 東京大学工学部建築学科 1991 年度卒業論文, 1991.12」。

注 9）「ヴェニス憲章, 1964」「「バラ憲章, 1981, 1999, 2013」、「奈良ドキュメ ント, 1994」、「マドリッドドキュメント, 2011」による。

\section{参考文献}

1）港区：旧国立保健医療科学院整備活用基本計画, 2013.8

2）川上悠介: 港区立港郷土資料館等複合施設整備工事について 旧国立公衆 衛生院の改修工事（特集 近代建築の保存・再生・活用）, BELCA NEWS, 160 号, pp.74-80, 2017.7

3）生き続ける建築-6 内田祥三, INAX REPORT, No.172, pp.4-16, 2007.10

4）田原幸夫ほか 2 名: 東京駅丸の内駅舎保存·復原におけるデザインプロセ ス, 日本建築学会技術報告集, 第 19 巻, 第 43 号, pp.1209-1214, 2013.10

5）東日本旅客鉄道株式会社：重要文化財東京駅丸の内駅舎保存・復原工事報 告書, 2013.7

[2018 年 2 月 5 日原稿受理 2018 年 3 月 23 日採用決定 $]$ 